\title{
Budaya Organisasi Berorientasi Hasil dan Komitmen Organisasi Sebagai Pemoderasi Pengaruh Partisipasi Penganggaran Pada Senjangan Anggaran
}

\author{
Putu Indah Widyasari ${ }^{1}$ \\ Ni Made Dwi Ratnadi ${ }^{2}$
}

\author{
${ }^{1,}$ Fakultas Ekonomi dan Bisnis Universitas Udayana (Unud), Bali, Indonesia \\ email: gek.indah96@yahoo.com/ Telp : 081338862272 \\ ${ }^{2}$ Fakultas Ekonomi dan Bisnis Universitas Udayana (Unud), Bali, Indonesia
}

\begin{abstract}
ABSTRAK
Anggaran merupakan alat untuk mengkomunikasikan rencana manajemen, mengalokasikan sumber daya, dan mengkoordinasikan aktivitas operasional maupun strategis perusahaan. Partisipasi karyawan dalam penganggaran dan penilaian kinerja berdasarkan anggaran dapat menyebabkan perilaku disfungsional dengan melakukan senjangan anggaran. Penelitian ini bertujuan untuk menguji secara empiris kemampuan budaya organisasi berorientasi hasil dan komitmen organisasi memoderasi pengaruh partisipasi penganggaran pada senjangan anggaran. Penelitian dilakukan di hotel bintang 3,4 dan 5 di Kota Denpasar. Responden dalam penelitian ini adalah kepala departemen yang terlibat dalam proses penyusunan dan pelaksanaan anggaran, berjumlah 84 responden. Teknik analisis yang digunakan adalah analisis regresi moderasi. Hasil analisis menunjukkan budaya organisasi berorientasi hasil dan komitmen organisasi memoderasi pengaruh partisipasi penganggaran pada senjangan anggaran. Semakin tinggi partisipasi penganggaran menyebabkan sejangan anggaran menjadi turun pada saat budaya organisasi berorientasi hasil dan komitmen organisasi tinggi.
\end{abstract}

Kata kunci: budaya organisasi, komitmen organisasi, partisipasi penganggaran, senjangan anggaran

\begin{abstract}
A budget is used by management to communicate plans, allocate resources, and coordinate operational activities and corporate strategies. Employee participation in budgeting and performance assessment based on budgets can lead to dysfunctional behavior by performing the budgetary slack. This study aims to empirically test the capability of organizational culture of results oriented and organizational commitment to moderate the influence of budgetary participation on budgetary slack. The study was conducted at 3.4 and 5 star hotels located in Denpasar. Respondents are Head of Department who is involved in the process of preparing and implementing the budget, amounting to 84 respondent. The analysis technique used is regression analysis of moderation. The results show that organizational culture that is result oriented and organizational commitment moderate the influence of budgetary participation on budgetary slack. The higher budgeting participation causes less budgetary slack when there is a high result-oriented organizational culture and organizational commitment.

Keywords: Organizational culture, commitment organizational, budgetary participation, budgetary slack
\end{abstract}




\section{PENDAHULUAN}

Anggaran dapat membantu manajemen untuk mengelola perusahaan dengan baik sehingga dapat mencapai tujuan jangka pendek dan jangka panjang perusahaan. Penggunaan anggaran sebagai alat bantu manajemen dalam mengelola perusahaan untuk menghindari inefisiensi dalam alokasi sumber daya perusahaan, karena dalam penyusunan anggaran tersebut berbagai aspek diperhatikan baik dari aspek internal hingga eksternal perusahaan dijadikan bahan pertimbangan dalam penyusunan anggaran.

Pello (2014) menyebutkan bahwa anggaran merupakan alat yang digunakan untuk mengkomunikasikan rencana-rencana manajemen, mengalokasikan sumber daya, dan mengkoordinasikan aktivitas operasional maupun startegis perusahaan. Selain anggaran dapat berfungsi sebagai alat perencanaan, anggaran juga dapat berfungsi sebagai alat pengendalian bagi manajemen guna melaksanakan kegiatan organisasi secara efektif dan efisien. Anggaran sebagai alat pengendalian disini barmakna bahwa anggaran yang disusun dijadikan patokan kinerja dari para bawahan. Sehingga atasan dapat memantau apakah pengelolaan sumberdaya perusahaan sudah berjalan dengan baik atau belum.

Penggunaan anggaran sebagai penilaian kinerja dapat menyebabkan terjadinya dysfunctional behavior atau penyimpangan perilaku para bawahan (Faria, 2013). Tidak dapat dipungkiri bahwa perilaku manusia yang membuat dan melaksanakan anggaran merupakan aspek yang perlu diperhatikan. Anggaran yang dibuat dapat dipengaruhi oleh aspek perilaku manusia, begitu juga sebaliknya pembuat dan pelaksana anggaran tersebut dapat dipengaruhi oleh 
adanya anggaran. Maka dari itu sebuah organisasi maupun perusahaan harus lebih memperhatikan perilaku manusia yang berhubungan dengan anggaran.

Menurut Ompusunggu dan Bawono (2006) penganggaran dilakukan dengan system topdown, dimana rencana dan jumlah anggaran telah ditetapkan oleh atasan atau pemegang kuasa anggaran sehingga bawahan atau pelaksana anggaran hanya melakukan apa yang telah disusun. Hal ini tentu akan mempersulit bawahan untuk mencapai target yang telah ditetapkan. Sehingga dalam penyusunan anggaran diperlukan keterlibatan semua tingkatan organisasi mulai dari manajemen tingkat atas sampai dengan manajemen tingkat bawah. Keterlibatan bawahan dalam penyusunan anggaran merupakan bentuk dari partisipasi anggaran. Adanya keterlibatan bawahan akan sangat memungkinkan mereka untuk memberi informasi lokal yang diketahui. Dengan cara ini, bawahan dapat mengkomunikasikan atau mengungkapkan beberapa informasi pribadi yang mungkin dapat dimasukkan dalam standar atau anggaran sebagai dasar penyusunan, namun jika bawahan diberi kebebasan tanpa batasan dalam menentukan target anggaran maka akan menimbulkan rendahnya motivasi bawahan dalam mencapai target yang optimal.

Pada kenyataannya, anggaran yang bersifat partisipasi ini sering disalahgunakan oleh bawahan dalam proses penyusunannya. Hal ini terjadi bila bawahan ingin kinerjanya dinilai baik oleh atasan dan anggaran dipandang sebagai suatu tekanan untuk mencapai prestasi tersebut (Siegel dan Marconi, 1989). Ali Maskun (2009) menyatakan bahwa bawahan akan membuat target anggaran yang lebih mudah dicapai dengan cara membuat target anggaran yang 
rendah pada sisi pendapatan dan mengajukan biaya yang lebih. Menurut Mowen (2002) partisipasi anggaran ini memunculkan beberapa masalah antara lain (1) menetapkan standar yang terlalu tinggi atau terlalu rendah, (2) membuat kelonggaran dalam anggaran, (3) partisipasi semu. Penilain kinerja berdasarkan tercapai atau tidaknya target anggaran inilah yang nantinya akan mendorong agen untuk melakukan senjangan anggaran.

Senjangan anggaran adalah kecenderungan berperilaku tidak produktif dengan melebihkan biaya saat seorang pegawai mengajukan anggaran belanja (Yuhertiana, 2009). Hal ini dapat menimbulkan senjangan anggaran yang akan berdampak buruk yaitu alokasi sumber daya kurang optimal dan ketidakadilan sumber daya di seluruh unit bisnis. Alokasi yang kurang optimal dapat menurunkan efisiensi perusahaan, sedangkan ketidakadilan dapat menggagalkan manajer unit bisnis yang menerima sumber daya relatif kecil dari unit bisnis lainnya.

Karyawan atau bawahan yang gagal dalam memenuhi target anggaran yang telah ditentukan akan terlihat memiliki kinerja yang lebih buruk dibandingkan karyawan atau bawahan yang berhasil memenuhi target anggaran yang telah ditentukan. Oleh karena itu untuk tahun kedepannya, karyawan atau bawahan tersebut akan mengusahakan agar target anggarannya lebih mudah untuk dicapai sehingga kinerja mereka terlihat lebih baik (Faria, 2013). Husain (2011) menyatakan bahwa senjangan anggaran dilakukan oleh bawahan dengan menyajikan anggaran dengan tingkat kesulitan yang lebih rendah agar dalam pencapaiannya menjadi lebih mudah sehingga kinerja mereka terlihat lebih baik. 
Beberapa penelitian mengenai senjangan anggaran telah relatif banyak dilakukan dan hasilnya masih menemukan ketidakkonsistenan. Christensen (1982), Falikhatun (2007) dan Pratama (2013) menyebutkan partisipasi penganggaran berpengaruh positif terhadap senjangan anggaran. Hal ini berarti adanya partisipasi karyawan didalam penyusunan anggaran dapat meningkatkan terjadinya senjangan anggaran. Sedangkan penelitian oleh Merchant (1985), Dunk (1993), dan Sujana (2010) menunjukkan bahwa partisipasi penganggaran berpengaruh negatif terhadap senjangan anggaran, yang berarti semakin tinggi partisipasi dalam penyusunan anggaran, maka kemungkinan terjadinya senjangan anggaran dapat dikurangi. Adanya partisipasi dalam penganggaran ini diharapkan mampu membantu jalannya penganggaran agar mencapai hasil yang baik.

Ketidakkonsistenan hasil penelitian tersebut yang melatarbelakangi penelitian ini untuk terus dilanjutkan dengan menambahkan variabel kontijensi. Govindarajan (1986) menyatakan bahwa perbedaan hasil dari penelitian sebelumnya bisa dipecahkan dengan menggunakan pendekatan kontinjensi. Hal tersebut dilakukan dengan cara memasukan variabel lain yang mungkin mempengaruhi hubungan partisipasi penganggaran pada budgetary slack. Variabel yang diperkirakan dapat mempengaruhi hubungan partisipasi penganggaran dengan budgetary slack tersebut budaya organisasi dan komitmen organisasi.

Budaya organisasi berorientasi hasil digunakan sebagai variabel moderasi dalam penelitian ini karena budaya organisasi merupakan asumsi-asumsi dasar serta keyakinan yang dimiliki oleh setiap anggota organisasi yang kemudian 
digunakan untuk mengatasi permasalahan internal maupun eksternal organisasi (Sri Utami, 2012). Menurut pendapat Sumarsih dan Wahyudi (2009), budaya organisasi adalah sebuah kesepakatan yang berupa norma maupun aturan yang akan dilaksanakan oleh semua anggota organisasi, sehingga dapat memberikan arah dan pedoman bagi setiap anggota organisasi dalam setiap tindakan dan pekerjaan. Organisasi harus dapat mengembangkan potensi sumber daya manusia dan juga memperkuat budaya organisasinya sehingga mampu menyesuaikan dengan keadaan yang berubah-ubah. Adanya pembentukan budaya organisasi yang baik akan menyebabkan karyawan lebih terpacu dalam bekerja agar tercapainya kinerja yang lebih tinggi dan meningkatkan kepuasan kerja serta kreativitas yang tinggi (Sami et al, 2011). Menurut Robbins (2015) ada tujuh karakteristik utama yang dapat menangkap intisari dari budaya organisasi adalah sebagai berikut (1) inovasi dan pengambilan risiko; (2) memperhatikan detail; (3) orientasi pada hasil; (4) orientasi pada orang; (5) orientasi pada tim; (6) keagresifan; (7) stabilitas.

Komitmen organisasi dapat mempengaruhi motivasi individu untuk melakukan sesuatu hal, termasuk partisipasinya dalam penyusunan anggaran (Febri, 2008) dalam Mahadewi (2014). Pengaruh komitmen organisasi terhadap hubungan antara partisipasi anggaran terhadap senjangan masih menghasilkan hasil yang tidak konsisten.Pada dasarnya komitmen organisasi merupakan suatu keterikatan antara anggota dengan organisasi. Komitmen organisasi yang kuat akan menjadikan individu peduli dengan nasib organisasi dan berusaha menjadikan organisasi ke arah yang lebih baik. Dengan adanya komitmen 
organisasi yang tinggi, maka senjangan anggaran akan dapat dihindari. Sebaliknya, jika individu memiliki komitmen organisasi yang rendah, maka akan memungkinkan terjadinya senjangan anggaran.

Holmes dan Marsden dalam Giusti (2013) mengemukakan budaya organisasi mempunyai pengaruh terhadap perilaku, cara kerja dan motivasi para manajer dan bawahan untuk mencapai kinerja organisasi. Budaya organisasi merupakan nilai-nilai kepercayaan yang dituangkan ke dalam bentuk normanorma yang dapat mempengaruhi cara individu bertindak dalam organisasi. Oleh karena itu, individu cenderung akan berbuat baik dan jujur dalam setiap tindakannya termasuk dalam proses penyusunan anggaran. Hal ini juga akan meningkatkan komitmen dan loyalitas anggota organisasi, sehingga anggota akan senantiasa berpartisipasi penuh dalam memajukan organisasinya serta mendorong keinginan anggota untuk lebih mementingkan kepentingan organisasi dibandingkan kepentingan pribadinya. Oleh sebab itu, budaya organisasi mampu memicu adanya penurunan senjangan anggaran. Tipe budaya organisasi yang digunakan dalam penelitian ini adalah budaya organisasi berorientasi pada hasil, yang mana manajemen menitikberatkan pada perolehan atau hasil dan bukan pada teknik dan proses yang digunakan untuk mencapainya.

Berdasarkan uraian diatas, hipotesis alternatif yang akan diuji adalah sebagai berikut:

$\mathrm{H}_{1}$ : Semakin tinggi tingkat partisipasi penganggaran, maka semakin tinggi senjangan anggaran, terutama bagi anggota organisasi yang menganut budaya organisasi berorientasi hasil yang rendah. 
Putu Indah Widyasari dan Ni Made Dwi Ratnadi. Budaya...

Komitmen menunjukkan keyakinan dan dukungan yang kuat terhadap nilai dan sasaran yang ingin dicapai organisasi. Tingkat komitmen yang dimiliki dalam pengaruhnya terhadap peningkatan atau penurunan senjangan anggaran dapat dilihat dari sejauh mana individu lebih mementingkan diri sendiri atau bekerja demi kepentingan organisasinya.

Hasil penelitian oleh Nouri dan Parker (1996), Latuheru (2005), Desmiyati (2009) dan Mahadewi (2014) menunjukka bahwa semakin tinggi tingkat komitmen terhadap suatu organisasi yang dimiliki oleh individu, maka akan mengurangi individu untuk melakukan senjangan anggaran. Hal ini diperkuat dengan hasil penelitian Dewi (2013) yang menyatakan bahwa interaksi anggaran partisipatif dan komitmen organisasi berpengaruh negatif dan signifikan terhadap senjangan anggaran.

Berdasarkan penjelasan yang telah diuraikan diatas, peneliti menduga bahwa komitmen organisasi memiliki pengaruh signifikan negatif terhadap hubungan partisipasi anggaran terhadap senjangan anggaran. Hal ini terjadi karena dengan adanya partisipasi yang tinggi dari bawahan serta dukungan yang kuat terhadap nilai dan sasaran yang ingin dicapai oleh organisasi menyebabkan menurunnya keinginan untuk melakukan senjangan anggaran. Berdasarkan uraian tersebut, dapat dirumuskan hipotesis sebagai berikut:

$\mathrm{H}_{2}$ : Semakin tinggi tingkat partisipasi penganggaran, maka semakin tinggi senjangan anggaran, terutama bagi anggota organisasi yang memiliki komitmen yang rendah. 


\section{METODE PENELITIAN}

Penelitian ini menggunakan pendekatan kuantitatif berbentuk asosiatif dengan hubungan kausalitas. Penelitian ini menjelaskan budaya organisasi berorientasi hasil dan komitmen organisasi sebagai pemoderasi pengaruh partisipasi anggaran pada senjangan anggaran. Desain penelitian ini dapat dilihat pada gambar berikut.

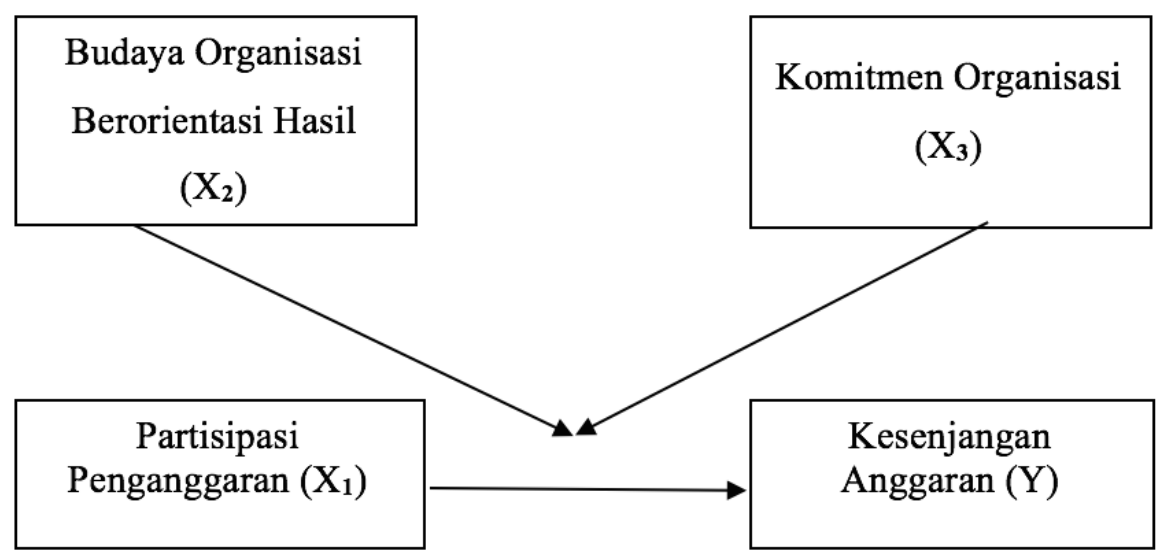

Gambar 1.

\section{Desain Penelitian}

Lokasi penelitian dilakukan di hotel berbintang tiga, empat dan lima di Kota

Denpasar yang berjumlah 19 hotel. Penelitian dilakukan pada hotel bintang tiga keatas karena pada umumnya hotel bintang tiga keatas memanfaatkan anggaran sebagai alat bantu manajemen lebih baik jika dibandingkan hotel bintang satu dan dua (Novitasari, 2015). Objek dari penelitian ini adalah senjangan anggaran. Peneliti menggunakan objek penelitian, yaitu pengaruh partisipasi penganggaran dengan dimoderasi oleh budaya organisasi berorientasi hasil dan komitmen organisasi di hotel bintang tiga sampai lima di Kota Denpasar.

Variabel terikat dalam penelitian ini adalah senjangan anggaran (Y) yang diukur dengan menggunakan enam indikator yaitu (1) standar dalam anggaran 
tidak mendorong peningkatan produktivitas. (2) Anggaran secara mudah untuk diwujudkan. (3) Tidak terdapatnya batasan-batasan yang harus di perhatikan terutama batasan yang ditetapkan untuk biaya. (4) Anggaran tidak menuntut hal khusus. (5) Anggaran tidak mendorong terjadinya efisiensi. (6) Target umum yang ditetapkan dalam anggaran mudah untuk dicapai. Variabel bebas dalam penelitian ini adalah Partisipasi Penganggaran $\left(\mathrm{X}_{1}\right)$ yang diukur dengan menggunakan empat indikator yaitu (1) Keikutsertaan dalam penyusunan anggaran. (2) Besarnya pengaruh terhadap penetapan anggaran akhir. (3) Kontribusi memberikan pendapatan. (4) Kepuasan dalam revisi penyusunan anggaran.

Variabel moderasi dalam penelitian ini adalah Budaya Organisasi Berorientasi Hasil $\left(\mathrm{X}_{2}\right)$ dan Komitmen Organisasi $\left(\mathrm{X}_{3}\right)$ yang masing-masing diukur dengan menggunakan indikator. Budaya Organisasi Berorientasi Hasil $\left(\mathrm{X}_{2}\right)$ diukur dengan menggunakan lima indikator yaitu (1) Bekerja dengan menekankan pada hasil yang optimal. (2) Mengembangkan diri untuk mendapatkan hasil yang optimal. (3) Meningkatkan efektivitas cara bekerja. (4) Menyelesaikan pekerjaan dengan cepat dengan hasil yang optimal. (5) Pemberian fasilitas oleh organisasi dalam menunjang penyelesaian pekerjaan secara optimal. Sedangkan Komitmen Organisasi $\left(\mathrm{X}_{3}\right)$ diukur dengan menggunakan delapan indikator yaitu (1) Usaha keras untuk menyukseskan organisasi. (2) Kebanggaan bekerja pada organisasi. (3) Kesediaan menerima tugas demi organisasi. (4) Kesamaan nilai individu dengan nilai organisasi. (5) Kebanggaan menjadi bagian dari organisasi. (6) Organisasi merupakan inspirasi untuk melaksanakan tugas. (7) Anggapan bahwa organisasi yang terbaik. (8) Perhatian terhadap nasib organisasi. 
Tiap-tiap jawaban diukur dengan menggunakan skala likert empat poin, yaitu skor 1= sangat tidak setuju (STS), skor $2=$ tidak setuju (TS), skor $3=$ setuju (S), skor 4 = sangat setuju (SS).

Populasi dalam penelitian ini adalah jumlah kepala departemen yang terlibat dalam proses penganggaran pada 19 hotel berbintang tiga sampai lima di Kota Denpasar. Pengumpulan sampel penelitian didasarkan pada metode purposive sampling. Metode pengumpulan data yang digunakan dalam penelitian ini adalah menggunakan kuisioner.

Jenis data yang digunakan dalam penelitian ini adalah data kuantitatif berupa skor dari jawaban kuisioner dan jumlah hotel berbintang tiga sampai lima di Kota Denpasar. Data kualitatif berupa nama hotel berbintang tiga sampai lima di Kota Denpasar yang diperoleh dari Dinas Pariwisata Kota Denpasar tahun 2017. Sedangkan sumber data yang digunakan dalam penelitian ini adalah data primer berupa hasil survei melalui kuisioner, dimana respondennya adalah Head of Departement yang terlibat dalam proses penganggaran pada hotel berbintang tiga sampai lima di Kota Denpasar. Data sekunder berupa daftar nama dan jumlah hotel berbintang tiga sampai lima di Kota Denpasar. Seluruh data sekunder tersebut bersumber dari publikasi resmi Dinas Pariwisata Kota Denpasar tahun 2017.

Teknik analisis data yang digunakan dalam penelitian ini adalah Moderated Regression Analysis (MRA). Data dianalisis dengan bantuan program Statistical Package for Social Science (SPSS). Persamaan regresi moderasi/ MRA:

$$
Y=\alpha+\beta_{1} X_{1}+\beta_{2} X_{2}+\beta_{3} X_{3}+\beta_{4} X_{1} X_{2}+\beta_{5} X_{1} X_{3}+e
$$


Keterangan:

$\mathrm{Y} \quad=$ Senjangan Anggaran

$\alpha \quad=$ Konstanta

$\mathrm{X}_{1} \quad=$ Variabel Partisipasi penganggaran

$\mathrm{X}_{2} \quad=$ Variabel Budaya Organisasi Berorientasi Hasil

$\mathrm{X}_{3} \quad=$ Variabel Komitmen Organisasi

$\mathrm{e} \quad=$ Standar Error

$\beta_{1 .} \beta_{2 .} \beta_{3 .} \beta_{4 .} \beta_{5 .}=$ Koefisien Regresi

Sebelum dilakukan pengujian hipotesis, data terlebih dahulu diuji asumsi klasik. Hal ini dilakukan untuk menghindari terjadinya estimasi bias mengingat tidak semua data dapat diterapkan regresi. Pengujian asumsi klasik meliputi uji normalitas, uji multikolinearitas dan uji heteroskedastisitas.

\section{HASIL DAN PEMBAHASAN}

Karakteristik demografi responden dalam penelitian ini adalah profil dari 84 kepala bagian dan staf yang menjadi responden dalam pengisian kuesioner penelitian. Karakteristik responden ini meliputi jenis kelamin, umur jabatan, pendidikan terakhir, dan lamanya menduduki jabatan tersebut yang dapat dilihat pada Tabel 1.

Tabel 1.

Karakteristik Responden

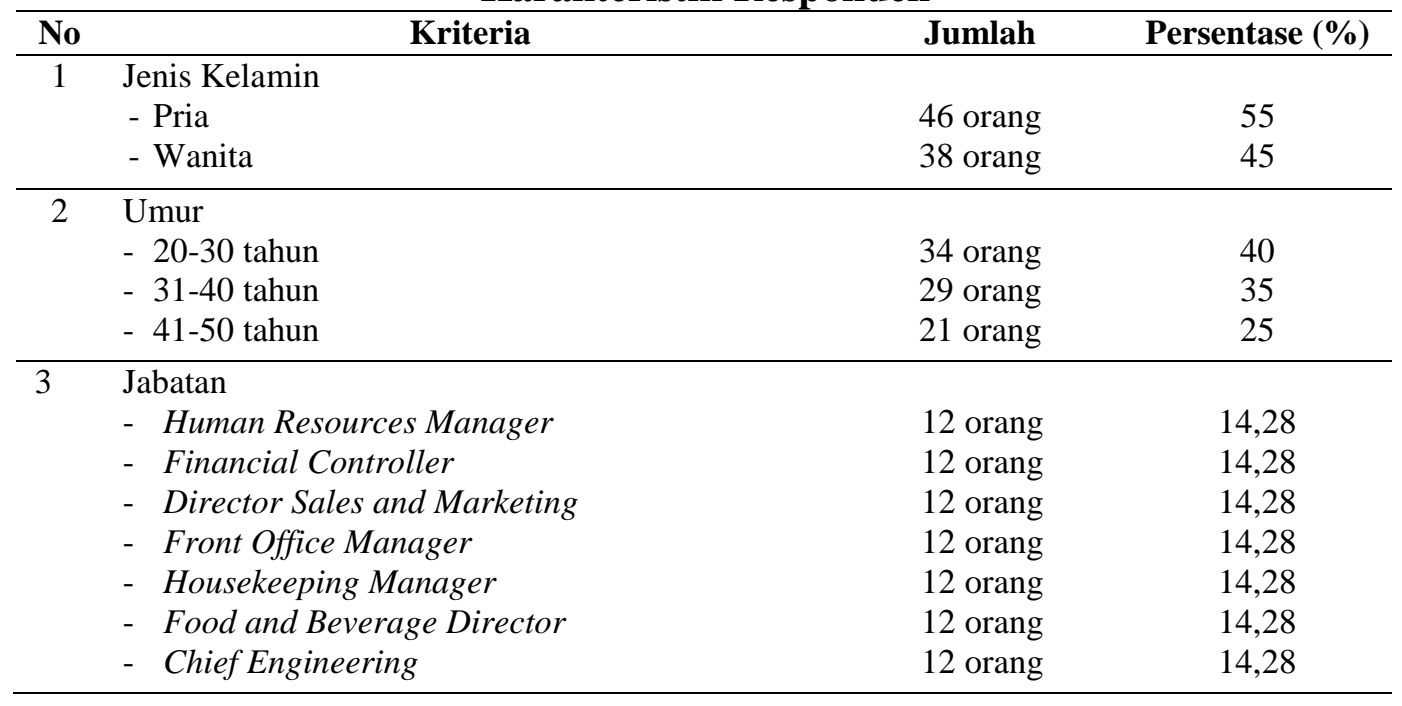




\begin{tabular}{|c|c|c|c|}
\hline \multirow[t]{5}{*}{4} & \multicolumn{3}{|l|}{ Pendidikan Terakhir } \\
\hline & - SMA/SMK & 4orang & 5 \\
\hline & - $\quad$ Diploma & 44orang & 52 \\
\hline & $\mathrm{S} 1$ & 36 orang & 43 \\
\hline & $\mathrm{S} 2$ & 0 orang & 0 \\
\hline \multirow[t]{5}{*}{5} & Lama Menduduki Jabatan/Bagian Tertentu & & \\
\hline & $-<1$ tahun & 0 orang & 0 \\
\hline & $-2-3$ tahun & 45 orang & 53 \\
\hline & - 4-10 tahun & 35 orang & 42 \\
\hline & $->10$ tahun & 4 orang & 5 \\
\hline
\end{tabular}

Sumber: Data Diolah, 2018

Berdasarkan Tabel 1. dapat disimpulkan bahwa responden yang berjenis kelamin pria berjumlah 46 orang dan berjenis kelamin wanita berjumlah 38 orang. Responden dalam penelitian ini yang berusia 20-30 tahun sebanyak 34 orang, berusia 31-40 tahun dengan jumlah 29 orang dan berusia 41-50 tahun sebanyak 21 orang.

Proporsi responden berdasarkan jabatan dibagi menjadi 7 klasifikasi. Untuk setiap hotel di Denpasar terdiri dari 7 kepala departemen yang terlibat dalam proses penyusunan rancangan anggaran. Untuk responden yang menduduki jabatan sebagai Human Resources Manager, Financial Controller, Director Sales and Marketing, Front Office Manager, Housekeeping Manager, Food and Beverage Director dan Chief Engineering masing-masing berjumah 12 orang. Klasifikasi responden berdasarkan jenjang pendidikan responden menghasilkan informasi bahwa pendidikan terakhir responden yang diteliti didominasi oleh responden dengan latar pendidikan terakhir diploma dan S1, sisanya berlatar belakang pendidikan SMA. Berdasarkan data yang diperoleh oleh peneliti tidak ditemukan responden yang memiliki pendidikan terakhir S2.

Data responden selanjutnya didasarkan pada lama bekerja responden. Berdasarkan Tabel 1., dapat dilihat lama bekerja responden dibagi menjadi 4 
klasifikasi waktu, yaitu kurang dari 1 tahun, 2 tahun sampai dengan 3 tahun, 4 tahun sampai dengan 10 tahun dan lebih dari 10 tahun. Berdasarkan data yang didapat, tidak terdapat responden yang memiliki masa kerja kurang dari 1 tahun. Untuk responden yang memiliki masa kerja dari 2 tahun sampai dengan 3 tahun berjumlah 45 orang. Untuk responden yang memiliki masa kerja dari 4 tahun sampai dengan 10 tahun berjumlah 35 orang dan untuk responden yang memiliki masa kerja lebih dari 10 tahun berjumlah 4 orang.

Statistik deskriptif dalam penelitian ini disajikan untuk memberikan informasi terkait tentang karakteristik variabel penelitian, antara lain nilai minimum, maksimum, mean dan standar deviasi. Tabel 2. memperlihatkan hasil uji statistik deskriptif.

Berdasarkan Tabel 2. dapat dilihat nilai minimum untuk variabel partisipasi penganggaran (X1) adalah 2 dan nilai maksimum adalah 4 . Untuk variabel budaya organisasi berorientasi hasil (X2) nilai minumumnya, yaitu 3 dan nilai maksimumnya, yaitu 4. Untuk variabel komitmen organisasi (X3) nilai minimum adalah 2 dan nilai maksimum adalah 4. Untuk variabel senjangan anggaran (Y) nilai minimumnya, yaitu 1 dan nilai maksimumnya, yaitu 4 .

Tabel 2.

Hasil Uji Statistik Deskriptif

\begin{tabular}{lccccc}
\hline & N & Minimum & Maximum & Mean & Std. Deviation \\
\hline X1 & 84 & 2 & 4 & 3.2 & 1.299 \\
X2 & 84 & 3 & 4 & 3.5 & 1.435 \\
X3 & 84 & 2 & 4 & 3.3 & 1.475 \\
Y & 84 & 1 & 4 & 3.2 & 1.632 \\
\hline Sumber: Data Diolah, 2018
\end{tabular}


Nilai mean dari variabel partisipasi penganggaran (X1) adalah 3,2 berarti responden cenderung setuju bahwa (1) responden ikut serta dalam penyusunan anggaran; (2) dalam penyusunan anggaran, besarnya pengaruh terhadap penetapan akhir; (3) responden berkontribusi memberikan pendapat; (4) adanya kepuasan dalam revisi penyusunan anggaran. Standar deviasi sebesar 1,299 berarti terjadi penyimpangan nilai partisipasi penganggaran terhadap nilai rata-ratanya sebesar 1,299 .

Untuk variabel budaya organisasi berorientasi hasil (X2) memiliki nilai mean sebesar 3,5 berarti responden cenderung setuju bahwa (1) responden bekerja dengan menekankan pada hasil yang optimal; (2) responden mengembangkan diri untuk mendapatkan hasil yang optimal; (3) responden meningkatkan efektivitas cara bekerja; (4) responden menyelesaikan pekerjaan dengan cepat dengan hasil yang optimal; (5) pemberian fasilitas oleh organisasi dalam menunjang penyelesaian pekerjaan secara optimal.Standar deviasi sebesar 1,435 berarti terjadi penyimpangan nilai budaya organisai terhadap nilai rata-ratanya sebesar 1,435 .

Nilai mean dari variabel komitmen organisai (X3), yaitu sebesar 3,3 berarti responden cenderung setuju bahwa (1) renponden berusaha keras untuk menyukseskan organisasi; (2) reponden bangga bekerja di organisasi sekarang; (3) responden bersedia menerima tugas demi organisasi; (4) adanya kesamaan nilai individu dengan nilai organisasi; (5) responden bangga menjadi bagian dari organisasi; (6) organisasi merupakan inspirasi untuk melaksanakan tugas. Standar 
Putu Indah Widyasari dan Ni Made Dwi Ratnadi. Budaya...

deviasi sebesar 1,475 berarti terjadi penyimpangan nilai komitmen organisasi terhadap nilai rata-ratanya sebesar 1,475 .

Untuk variabel senjangan anggaran (Y) memiliki nilai mean sebesar 3,2 berarti responden cenderung setuju bahwa (1) standar dalam anggaran tidak mendorong peningkatan produktivitas; (2) anggaran secara mudah untuk diwujudkan; (3) tidak terdapatnya batasan-batasan yang harus diperhatikan terutama batasan yang ditetapkan untuk biaya; (4) anggaran tidak menuntut hal khusus; (5) anggaran tidak mendorong terjadinya efisiensi; (6) target umum yang ditetapkan dalam anggaran mudah untuk dicapai. Nilai standar deviasi sebesar 1,632 yang berarti terjadi penyimpangan nilai senjangan anggaran terhadap nilai rata-ratanya sebesar 1,632 .

Uji validitas digunakan untuk mengukur valid tidaknya suatu kuisioner. Nilai koefisien yang positif dan lebih besar dari 0,3 mengindikasikan bahwa indikator yang digunakan tersebut valid. Tabel 3. memperlihatkan hasil uji validitas.

Tabel 3.

Hasil Uji Validitas

\begin{tabular}{cccc}
\hline Variabel & Instrumen & Pearson Correlation & Keterangan \\
\hline & X1.1 & 0,411 & Valid \\
Partisipasi Penganggaran & X1.2 & 0,456 & Valid \\
(X1) & X1.3 & 0,395 & Valid \\
& X1.4 & 0,662 & Valid \\
& X1.5 & 0,578 & Valid \\
\hline & X2.1 & 0,355 & Valid \\
X2.2 & 0,324 & Valid \\
Budaya Organisasi & X2.3 & 0,359 & Valid \\
Berorientasi Hasil & X2.4 & 0,467 & Valid \\
(X2) & X2.5 & 0,310 & Valid \\
& X2.6 & 0,327 & Valid \\
& X2.7 & 0,496 & Valid \\
& X2.8 & 0,377 & Valid \\
\hline & X3.1 & 0,404 & Valid \\
& X3.2 & 0,316 & Valid
\end{tabular}




\begin{tabular}{cccc} 
Komitmen Organisasi & X3.4 & 0,346 & Valid \\
(X3) & X3.5 & 0,448 & Valid \\
& X3.6 & 0,322 & Valid \\
& X3.7 & 0,426 & Valid \\
& X3.8 & 0,311 & Valid \\
\hline Senjangan Anggaran & Y.1 & 0,925 & Valid \\
(Y) & Y.2 & 0,872 & Valid \\
& Y.3 & 0,818 & Valid \\
& Y.4 & 0,790 & Valid \\
& Y.5 & 0,851 & Valid \\
\hline
\end{tabular}

Sumber: Data Diolah, 2018

Hasil uji validitas instrumen penelitian disajikan pada Tabel 3. yang menunjukkan bahwa seluruh indikator dalam variabel partisipasi penganggaran, budaya organisasi berorientasi hasil, komitmen organisasi, dan senjangan anggaran memiliki nilai pearson correlation yang lebih besar dari angka 0,30 sehingga seluruh indikator tersebut dikatakan telah memenuhi syarat validitas data.

Uji reliabilitas mampu menunjukan sejauh mana instrument dapat dipercaya dan diharapkan. Nilai suatu instrument dikatakan reliable apabila nilai Alpha Cronbach $\geq 0,70$. Hasil uji reliabilitas dapat dilihat pada Tabel 4 .

Tabel 4.

Hasil Uji Reliabilitas

\begin{tabular}{lcc}
\hline \multicolumn{1}{c}{ Variabel } & Cronbach's Alpha & Keterangan \\
\hline Partisipasi Penganggaran & 0,741 & Reliabel \\
Budaya Organisasi Berorientasi Hasil & 0,718 & Reliabel \\
Komitmen Organisasi & 0,769 & Reliabel \\
Senjangan Anggaran & 0,877 & Reliabel \\
\hline
\end{tabular}

Sumber: Data Diolah, 2018

Hasil uji reliabilitas instrumen pada penelitian ini disajikan pada Tabel 4 . yang menunjukkan bahwa keempat instrumen penelitian yaitu partisipasi penganggaran, budaya organisasi berorientasi hasil, komitmen organisasi, dan senjangan anggaran memiliki koefisien cronbach's alphayang lebih besar dari angka 0,70 sehingga pernyataan pada kuesioner dapat dikatakan reliabel. 
Putu Indah Widyasari dan Ni Made Dwi Ratnadi. Budaya...

Uji normalitas menggunakan uji Kolmogorov-Smirnov, dengan uji ini dapat diketahui data yang digunakan berdistribusi normal atau tidak. Apabila Asymp. Sig (2-Tailed) $>$ a $(0,05)$, maka dikatakan data terdistribusi normal. Tabel 5. memperlihatkan hasil uji normalitas.

Tabel 5.

Hasil Uji Normalitas

\begin{tabular}{|c|c|c|}
\hline \multirow[t]{2}{*}{ Model } & \multicolumn{2}{|c|}{ Colinearity Statistic } \\
\hline & Tolerance & VIF \\
\hline $\mathrm{X} 1$ & 0,206 & 2,633 \\
\hline $\mathrm{X} 2$ & 0,114 & 2,658 \\
\hline $\mathrm{X} 3$ & 0,227 & 1,960 \\
\hline $\mathrm{X} 1 * \mathrm{X} 2$ & 0,102 & 4,389 \\
\hline $\mathrm{X} 1 * \mathrm{X} 3$ & 0,253 & 6,073 \\
\hline
\end{tabular}

Sumber: Data Diolah, 2018

Berdasarkan hasil analisis, dapat dilihat bahwa koefisien Tolerance semua variabel lebih besar dari 0,10 dan nilai VIF yang lebih kecil dari 10. Hasil ini mengindikasikan bahwa tidak terdapat gejala multikolinearitas dari model regresi yang dibuat sehingga pada model regresi ditemukan korelasi antar variabel bebas.

Uji Heteroskedastisitas bertujuan untuk menguji apakah dalam model terjadi ketidaksamaan varian atau residual satu pengamatan ke pengamatan lainnya. Jika tingkat signifikan lebih besar dari 0,05 maka terjadi heteroskedastisitas. Tabel 7. memperlihatkan hasil uji heteroskedastisitas.

Tabel 7.

Hasil Uji Heteroskedastisitas

\begin{tabular}{|c|c|c|}
\hline Model & Sig. & Keterangan \\
\hline $\mathrm{X} 1$ & 0,171 & Lolos Uji \\
\hline $\mathrm{X} 2$ & 0,320 & Lolos Uji \\
\hline $\mathrm{X} 3$ & 0,861 & Lolos Uji \\
\hline $\mathrm{X} 1 * \mathrm{X} 2$ & 0,417 & Lolos Uji \\
\hline $\mathrm{X} 1 * \mathrm{X} 3$ & 0,746 & Lolos Uji \\
\hline
\end{tabular}

Sumber: Data Diolah, 2018 
Untuk mengetahui ada atau tidaknya heteroskedastisitas yaitu dengan melakukan uji glejser dengan meregresi nilai absolut terhadap variabel independen, dengan ketentuan jika nilai signifikan diatas 0,05 maka memiliki arti tidak terjadi heteroskedastisitas. Hasil uji menunjukkan nilai signifikansi lebih dari 0,05 yang artinya model regresi bebas dari gejala heteroskedastisitas.

Analisis regresi moderasi berguna untuk mengetahui kemampuan budaya organisasi berorientasi hasil dalam memoderasi pengaruh partisipasi penganggaran pada senjangan anggaran dan untuk mengetahui kemampuan komitmen organisasi dalam memoderasi pengaruh partisipasi penganggaran pada senjangan anggaran. Sesuai dengan hasil perhitungan dengan menggunakan program SPSS for windows maka diperoleh hasil analisis regresi moderasi seperti berikut.

Persamaan regresi yang digunakan dalam penelitian ini dapat ditulis sebagai berikut:

$$
Y=-51,810+0,883 X_{1}-0,848 X_{2}-0,729 X_{3}-0,111 X_{1} X_{2}-0,094 X_{1} X_{3}
$$

Tabel 8.

Hasil Uji MRA

\begin{tabular}{llllll}
\hline \multirow{2}{*}{ Model } & \multicolumn{2}{c}{ Unstandardized Coefficients } & $\begin{array}{c}\text { Standardized } \\
\text { Coefficients }\end{array}$ & t & Sig. \\
\cline { 2 - 5 } & \multicolumn{2}{c}{$\boldsymbol{\beta}$} & Std. Error & Beta & \\
\hline (Constant) & $-51,810$ & 27,008 & & $-1,918$ & 0,059 \\
$\mathrm{X} 1$ & 0,883 & 1,688 & 3,091 & 2,300 & 0,024 \\
$\mathrm{X} 2$ & $-0,848$ & 1,736 & 1,625 & $-1,065$ & 0,028 \\
$\mathrm{X} 3$ & $-0,729$ & 1,343 & 1,563 & $-1,287$ & 0,022 \\
$\mathrm{X} 1 * \mathrm{X} 2$ & $-0,111$ & 0,109 & $-2,387$ & $-1,019$ & 0,011 \\
$\mathrm{X} 1 * \mathrm{X} 3$ & $-0,094$ & 0,082 & $-2,219$ & $-1,144$ & 0,043 \\
\hline $\mathrm{R}$ & 0,429 & & & & \\
$\mathrm{R}^{2}$ & 0,484 & & & & \\
Adjusted R & 0,432 & & & & \\
F hitung & 13,527 & & & &
\end{tabular}


Putu Indah Widyasari dan Ni Made Dwi Ratnadi. Budaya...

Nilai konstanta $(\alpha)$ sebesar $-51,810$. Nilai konstanta tersebut bernilai negatif memiliki arti tanpa adanya partisipasi penganggaran $\left(\mathrm{X}_{1}\right)$, budaya organisasi berorientasi hasil $\left(\mathrm{X}_{2}\right)$, komitmen organisasi $\left(\mathrm{X}_{3}\right)$, interaksi antara partisipasi penganggaran dengan budaya organisasi berorientasi hasil $\left(\mathrm{X}_{1} \mathrm{X}_{2}\right)$ dan interaksi antara partisipasi penganggaran dengan komitmen organisasi $\left(\mathrm{X}_{1} \mathrm{X}_{3}\right)$, maka kinerja senjangan anggaran (Y) akan menurun sebesar 51,810.

Nilai p-value untuk variabel budaya organisasi berorientasi hasil sebesar $0,011<\alpha=0,05$ dengan nilai koefisien interaksi sebesar $-0,111$. Hasil ini menunjukan bahwa budaya organisasi berorientasi hasil memoderasi dengan memperlemah pengaruh partisipasi penganggaran terhadap senjangan anggaran. Dengan demikian maka $\mathrm{H}_{1}$ diterima. Nilai koefisien interaksi partisipasi penganggaran dengan budaya organisasi berorientasi hasil sebesar $-0,111$ memiliki arti apabila semua variabel lainnya konstan, sementara variabel interaksi partisipasi penganggaran dengan budaya organisasiberorientasi hasil naik sebesar 0,111 maka senjangan menurun sebesar 0,111.

Nilai p-value untuk variabel komitmen organisasi sebesar $0,043<\alpha=0,05$ dengan nilai koefisien interaksi sebesar -0,043. Hasil ini menunjukan bahwa komitmen organisasi memoderasi dengan memperlemah pengaruh partisipasi penganggaran terhadap senjangan anggaran. Dengan demikian maka $\mathrm{H}_{2}$ diterima. Nilai koefisien interaksi partisipasi penganggaran dengan komitmen organisasi sebesar -0,043 memiliki arti apabila semua variabel lainnya konstan, sementara 
variabel interaksi partisipasi penganggaran dengan komitmen organisasi naik sebesar 0,043 maka senjangan menurun sebesar 0,043.

Berdasarkan Tabel 8. menunjukkan bahwa koefisien determinasi yaitu nilai adjusted $R^{2}$ adalah 0,484 yang artinya sebesar 48,4 persen variasi senjangan anggaran dipengaruhi oleh variasi partisipasi penganggaran dengan budaya organisasiberorientasi hasil dan komitmen organisasi sebagai pemoderasi, sedangkan sisanya sebesar 51,6 persen dipengaruhi oleh faktor-faktor lain yang tidak dimasukkan ke dalam model.

Uji kelayakan model bertujuan untuk mengetahui apakah model regresi yang digunakan dalam penelitian ini layak atau tidak digunakan sebagai alat analisis untuk menguji pengaruh variabel bebas pada variabel terikatnya. Berdasarkan Tabel 8., nilai signifikansi $\mathrm{F}$ adalah sebesar 0,006 yang lebih kecil dari $0,05(\mathrm{~F}<\alpha)$ yang berarti variabel bebasyaitu partisipasi penganggaran $\left(\mathrm{X}_{1}\right)$ serta budaya organisasiberorientasi hasil $\left(\mathrm{X}_{2}\right)$ dan komitmen organisasi $\left(\mathrm{X}_{3}\right)$ sebagai pemoderasi berpengaruh signifikan secara serempak atau bersama-sama terhadap variabel terikat yaitu senjangan anggaran (Y), sehingga penelitian ini dapat dikatakan memenuhi uji kelayakan model atau model penelitian dinyatakan layak digunakan sebagai model regresi.

Hipotesis pertama menyatakan semakin tinggi partisipasi penganggaran, maka semakin tinggi senjangan anggaran, terutama bagi anggota organisasi yang menganut budaya organisasi berorientasi hasil yang rendah. Hasil analisis menunjukan bahwa budaya organisasi berorientasi hasil memoderasi partisipasi penganggaran pada senjangan anggaran. Hal ini berarti semakin tinggi partisipasi 
penganggaran menyebabkan senjangan anggaran menjadi turun pada saat budaya organisasi berorientasi hasil tinggi. Temuan penelitian ini menunjukan bahwa semakin rendah tingkat budaya organisasi beroirentasi hasil yang dianut oleh individu di suatu organisasi, maka akan menguatkan individu untuk melakukan senjangan anggaran. Tetapi, individu yang menganutbudaya organisasi berorientasi hasil yang tinggi, akan memiliki pandangan positif dan lebih berusaha berbuat yang terbaik demi kepentingan organisasi.

Penelitian ini mengkonfirmasi teori yang dikemukakan oleh Holmes dan Marsden dalam Giusti (2013) bahwa budaya organisasi mempunyai pengaruh terhadap perilaku, cara kerja dan motivasi para manajer dan bawahan untuk mencapai kinerja organisasi. Budaya organisasi merupakan nilai-nilai kepercayaan yang dituangkan ke dalam bentuk norma-norma yang dapat mempengaruhi cara individu bertindak dalam organisasi. Oleh karena itu, individu akan cenderung berbuat baik dan jujur dalam setiap tindakannya termasuk dalam proses penyusunan anggaran.

Hipotesis kedua menyatakan semakin tinggi partisipasi penganggaran, maka semakin tinggi senjangan anggaran, terutama bagi anggota organisasi yang memiliki komitmen organisasi yang rendah. Hasil analisis menunjukan bahwa komitmen organisasi memoderasi partisipasi penganggaran pada senjangan anggaran. Hal ini berarti semakin tinggi partisipasi penganggaran menyebabkan senjangan anggaran menjadi turun pada saat komitmen organisasi tinggi .Temuan penelitian ini menunjukan bahwa semakin rendah tingkat komitmen terhadap suatu organisasi yang dimiliki oleh individu, maka akan menguatkan individu 
untuk melakukan senjangan anggaran. Tetapi, individu yang memiliki tingkat komitmen organisasi yang tinggi, akan memiliki pandangan positif dan lebih berusaha berbuat yang terbaik demi kepentingan organisasi. Penelitian ini sejalan dengan penelitian yang dilakukan oleh Nouri dan Parker (1996), Latuheru (2005), Desmiyati (2009) dan Mahadewi (2014) menunjukan bahwa semakin tinggi tingkat komitmen terhadap suatu organisasi yang dimiliki oleh individu, maka akan mengurangi individu untuk melakukan senjangan anggaran.

\section{SIMPULAN}

Berdasarkan pembahasan hasil penelitian di atas, dapat disimpulkan bahwa Budaya organisasi berorientasi hasil memoderasi pengaruh partisipasi penganggaran pada senjangan anggaran di hotel berbintang 3 sampai 5 di Kota Denpasar. Komitmen organisasi dapat memoderasi pengaruh partisipasi penganggaran pada senjangan anggaran di hotel berbintang 3 sampai 5 di Kota Denpasar. Sedangkan saran yang dapat diberikan adalah untuk peneliti selanjutnya diharapkan mengukur dengan menggunakan variabel lain yang juga dapat memoderasi hubungan positif pengaruh partisipasi pengganggaran terhadap senjangan anggaran, seperti variabel gaya kepemimpinan. Selain hal tersebut, diharapkan juga untuk meneliti senjangan anggaran pada industri lain yang menggambarkan fenomena senjangan anggaran terjadi.

\section{REFERENSI}

Ali, M. (2009). Analisis Faktor, Budaya Birokrasi, Tekanan Sosial, dan Kapasitas Individu terhadap Senjangan Anggaran (Kajian Perilaku Eksekutif dalam Proses Penyusunan Anggaran di Badan Koordinator Wilayah II Jawa Timur. Jurnal Aplikasi Manajemen, 7(1), 162-172. 
Anthony dan Govindarajan. (2005). Management Control System. Buku 2. Edisi ke11 penerjemah: F.X. Kurniawan Tjakrawala, dan Krista. Jakarta: Salemba Empat.

Burhanudin. (2009). Pengaruh Partisipasi Anggaran Terhadap Senjangan Anggaran: Komitmen Organisasional dan Ketidakpastian Lingkungan sebagai Variabel Pemoderasi (Studi Kasus di BMT se-Yogyakarta). Jurnal Ekonomi. Fakultas Syariah Universitas Negeri Islam Sunan Kalijaga.

Christensen, J. (1982). The Determination Of Performance Standards And Participation. Journal of Accounting Research, 20(2), 589-603.

Dunk, A. S. (1993). The Effect of Budget Emphasis and Information Assymetri on Relation Between Budgetary Participation and Slack. The Accounting Review, 68(2), 400-410.

Falikhatun. (2007). Interaksi Informasi Asimetri, Budaya Organisasi dan Group Cohesiveness dalam Hubungan Antara Partisipasi Penganggaran dan Budgetary Slack. Symposium Nasional Akuntansi X.

Faria, J. A. D dan Silva, S. M. G. D. (2013). The Effects on Information Asymetry on Budget Slack: A Experimental Research. Academic Journal, 7(13), 1086-1099.

Ghozali, I. (2013). Aplikasi Analisis Multivariate dengan Program SPSS. Edisi 7. Semarang: Universitas Diponogoro.

Giusti, G. (2013). Pengaruh Partisipasi Anggaran terhadap Senjangan Anggaran dengan Budaya Organisasi sebagai Variabel Moderating Studi Kasus pada SKPD Kota Jember. Jurnal Akuntansi.

Govindarajan, V. (1986). Impact of Participation in the Budgetary Process on Managerial Attidues and Perfomance: Universalitic and Contigency Perspective. Decision Sciences, 17, 496-516.

Hansen and Mowen. (2006). Management Accounting. Buku 1. Edisi 7. Jakarta: Erlangga.

Husain, S. P. (2011). Pengaruh Partisipasi Anggaran Terhadap Senjangan Anggaran dengan Komitmen Organisasi sebagai Variabel Moderating. Jurnal Akuntansi, 8(3).

Ikhsan, A. (2011). Akuntasi Keprilakuan. Edisi Kedua. Jakarta: Salemba Empat. 
Jensen, M. and Meckling, W. (1976). A Theory of The Firm: Managerial Behavior, Agency Cost, and Ownership Structure. Journal of Financial Economic, 3(4), 305-360.

Lavarda, C. dan Dalci, M. A. (2013). Budget Participation and Informational Asymetry: a study in a multinational company. Brazilian Business Review, 10(2), 474-488.

Mahadewi, A. A. S. S. (2014). Pengaruh Partisipasi Penganggaran pada Senjangan Anggaran dengan Asimetri Informasi dan Komitmen Organisasi sebagai Pemoderasi. Fakultas Ekonomi dan Bisnis Universitas Udayana.

Merchant, K. A. (1985). Budgeting and Propersity to Create Budgetary Slack. Accounting, Organization, and Society, 10, 201-210.

Mercury, G. A. (2015). Pengaruh Partisipasi Penganggaran dan Informasi Asimetri pada Senjangan Anggaran dengan Budaya Organisasi sebagai Variabel Moderasi (Studi Empiris pada Hotel Berbintang di Kabupaten Gianyar). E-Jurnal Akuntansi, 13(3), 1070-1099.

Mulyadi. (2001). Sistem Akuntansi. Edisi ketiga. Jakarta: Salemba Empat.

Nafarin, M. (2007). Penganggaran Perusahaan. Jakarta: Salemba Empat.

Nouri and Parker, R. J. (1996). The Effect of Organizational Commitment on the Relation between Budgetary Participation and Budgetary Slack. Behavioral Research in Accounting, 8, 74-90.

Novitasari, N. dan Wirama, D. G. (2015). Pengaruh Pengendalian Anggaran pada Senjangan Anggaran dan Orientasi Jangka Pendek Manajer. E-Jurnal Akuntansi, 15(3), 2024-2051.

Ompusunggu, K. B. dan Bawono, I. R. (2006). Pengaruh Partisipasi Anggaran dan Job Relevant Information (JRI) terhadap Informasi Asimetris (Studi pada Badan Layanan Umum Universitas Negeri di Kota Purwokerto, Jawa Tengah). Simposium Nasional Akuntansi, 9.

Otley, D. T. (1980). The Contingency Theory of Management Accounting Achievement and Prognosis. Accounting Organizations and Society, 5(4), 413-428.

Ozer, G. and Yilmaz, E. (2011). Effect of Procedural Justice Perception, Budgetary Control Effectiveness and Ethical Work Climate on Propensity to Create Budgetary Slack. Business and Economic Research Journal, 2(4), 1-18. 
Pello, E. V. (2014). Pengaruh Asimetri Informasi, Locus of Control pada Hubungan antara Penganggaran Partisipatif dengan Senjangan Anggaran. E-jurnal Akuntansi, 6(2), 287-305.

Pratama, R. (2013). Pengaruh Partisipasi Anggaran terhadap Senjangan Anggaran dengan Komitmen Organisasi dan Motivasi Sebagai Pemoderasi (Studi Empiris pada Satuan Kerja Perangkat Daerah di Kota Padang). Jurnal Akuntansi, Universitas Negeri Padang.

Pratami, A. A. S. D. (2015). Pengaruh Partisipasi Penganggaran terhadap Senjangan Anggaran dengan Penekanan Anggaran dan Ketidakpastian Lingkungan sebagai Pemoderasi. E-Jurnal Akuntansi, 15(2), 1565-1594.

Siegel, G. dan Marconi, H. R. (1989). Behavioural Accounting. South Western Publishing Company.

Sri, U. dan Fuji, R. (2012). Pengaruh Interaksi Budaya Organisasi dan Group Cohesiveness dalam Hubungan Antara Partisipasi Penganggaran dan Senjangan Anggaran (Studi Empiris pada Instansi Pemerintahan (SKPD) Kabupaten Dharmasraya. Fakultas Ekonomi Negeri Padang.

Sugiyono. (2014). Metode Penelitian Bisnis. Bandung: CV. Alfabeta.

Sujana, I. K. (2010). Pengaruh Partisipasi Penganggaran, Penekanan Anggaran, Komitmen Organisasi, Asimetri Informasi, dan Ketidakpastian Lingkungan terhadap Senjangan anggaran. Audit Jurnal Akuntansi dan Bisnis, 5(2).

Utama, M. S. (2014). Aplikasi Analisis Kuantitatif. Edisi ke-8. Buku Ajar Kuliah pada Fakultas Ekonomi dan Bisnis Universitas Udayana.

Wiener, Y. (1982). Commitment in Organizations: A normative view. Academy of Management Review, 7, 418-428.

Wiguna, I. W. A. (2016). Komitmen Organisasi dan Asimetri Informasi sebagai Pemoderasi Pengaruh Kejelasan Sasaran Anggaran pada Senjangan Anggaran. E-Jurnal Akuntansi, 16(3), 2435-2456.

Winarni, T. T. (2014). Analisis Pengaruh Partisipasi Anggaran, Budget emphasis, dan Informasi Asimetris terhadap Slack Anggaran (Studi pada Satuan Kerja Pemerintah Daerah Kabupaten Wonogiri). Naskah Publikasi, Universitas Muhammadiyah Surakarta.

Yuhertiana, I. (2005). Kajian Etika Budgetary Slack di Organisasi Sektor Publik Menurut Perspektif Gender. Simposium Riset Ekonomi II, Surabaya. 
Yuhertiana, I. (2009). Menggali Peluang Baru Penelitian di Ranah Akuntansi Keperilakuan Sektor Publik. Fakultas Ekonomi UPN Veteran, Jawa Timur. 